\title{
Organisatiecriminaliteit en de aanpak ervan in de Lage Landen
}

\author{
Karin Van Wingerde, Antoinette Verhage \& Lieselot Bisschop
}

In dit inleidende artikel gaan we in op enkele ontwikkelingen in het onderzoek naar organisatiecriminaliteit dat in Nederland en Belgie sinds 2008 is verricht. Dat doen we aan de hand van drie vragen: (1) Wat zijn de belangrijkste ontwikkelingen in de wijze waarop onderzoek naar organisatiecriminaliteit wordt verricht? (2) Waar gaat het onderzoek over? Wat zijn de belangrijkste thema's? (3) Wat missen we en wat zijn de belangrijkste blinde vlekken in onderzoek naar organisatiecriminaliteit?

\section{Inleiding}

'There is no excuse for anyone to ever make an error in financial decisionmaking.' Dat zei Harvard-psycholoog Dan Gilbert in zijn keynote speech op de zogeheten Think Forward Summit, die in april 2018 plaatsvond in Amsterdam. Het Think Forward Initiative is een initiatief dat de ING Bank samen met enkele andere partners enkele jaren geleden lanceerde om beter te begrijpen hoe mensen financiële beslissingen nemen, waarom ze veelal kortetermijnwensen plaatsen boven toekomstige en daardoor verkeerde beslissingen nemen, en om mensen voor verkeerde financiële beslissingen te behoeden. Toen het Openbaar Ministerie $(\mathrm{OM})$ begin september 2018 bekendmaakte dat het een recordschikking van 775 miljoen euro had getroffen met ING, werd echter pijnlijk duidelijk dat de bank eraan voorbij was gegaan om die vragen ook aan zichzelf te stellen.

Met de schikking, bestaande uit een boete van 675 miljoen euro en ontneming van het wederrechtelijk verkregen voordeel van 100 miljoen euro, kocht ING strafvervolging af voor het jarenlang en op structurele wijze overtreden van de Wet ter voorkoming van witwassen en financieren van terrorisme (Wwft). De Wwft verplicht banken en andere dienstverleners een onderzoek uit te voeren naar hun cliënten om te voorkomen dat zij die diensten misbruiken om illegaal vergaard vermogen wit te wassen of ten behoeve van de financiering van terrorisme. De dienstverleners zouden dus als poortwachters moeten functioneren om de integriteit van het financiële stelsel te beschermen. Het verwijt aan ING is dat zij haar rol als poortwachter onvoldoende heeft ingevuld, waardoor criminelen misbruik hebben kunnen maken van ING-rekeningen en daardoor grote sommen geld via Nederlandse rekeningen hebben kunnen witwassen.

Gelijktijdig met de schikking publiceerde het OM een uitgebreid feitenrelaas waarin verslag werd gedaan van het strafrechtelijk onderzoek tegen ING (OM, 2018). Daaruit komt een schokkend beeld van de interne bedrijfsvoering bij de 
bank naar voren. Niet alleen werd het cliëntonderzoek niet goed uitgevoerd waardoor dossiers ontbraken of onvolledig waren, ook bleek het interne monitoringssysteem - dat juist bedoeld was om signalen van witwassen op te pakken - voor sommige categorieën signalen gemaximeerd te zijn op slechts drie signalen per dag (OM, 2018, 11). Daardoor heeft de bank belangrijke signalen van witwassen gemist. De oorzaak van dit alles ligt volgens het OM in een bedrijfscultuur waarin bezuinigingen ten koste zijn gegaan van compliance. Er was een structureel tekort aan voldoende opgeleid personeel om signalen van witwassen te beoordelen (OM, $2018,12)$. Ook wilde de bank een aantrekkelijk acceptatieproces bieden aan haar klanten (OM, 2018, 9). Het 'onboarden' van nieuwe klanten kreeg zo prioriteit boven het afronden van due diligence-onderzoek en het onderzoeken van fraudesignalen. Tot slot ontbrak bij het management de juiste 'tone at the top' voor goed compliancebeleid. Met andere woorden: business ging boven compliance (OM, 2018, 17).

Ongeveer tegelijk met de ING-affaire speelde zich in België een vergelijkbare zaak af. In mei 2018 legde de toezichthouder (de Nationale Bank) aan BNP Paribas Fortis een boete van 300.000 euro op wegens een 'tekortgeschoten en ineffectief' monitoringsysteem (Nationale Bank, 2018). Ook hier bleken jarenlang en stelselmatig transacties niet gemonitord te worden en werd het Know Your Customerbeleid zeer zwak opgevolgd. Daardoor kon een neef van Khadaffi jarenlang een rekening aanhouden bij de bank. Dit leidde er onder andere toe dat de rekening werd gebruikt voor het overschrijven van grote sommen geld, ook naar tax havens (Dubai) en hoogrisicolanden (zoals Libië), en dat de klant probleemloos een krediet van ruim 80.000 euro werd verleend voor de aankoop van ruim 1.000 kogelvrije vesten (Bové \& Broens, 2018). BNP Paribas Fortis werd onder andere verweten dat ze de klant onterecht een 'medium' risicoprofiel had toegekend in 2010 (na aanvaarding van de klant in 2005), dat ze veel te hoge maximumbedragen hanteerde voordat er alarmbellen afgingen (die gingen pas af als er meer dan 750.000 euro werd overgemaakt in een periode van zeven dagen en bij hoogrisicolanden pas bij bedragen vanaf 375.000 euro per zeven dagen), en dat atypische transacties niet werden getraceerd, noch door eerstelijnsmedewerkers, noch in de tweede lijn (door compliance). Door de jaren heen gingen er wel een aantal alarmen af bij de interne complianceafdeling, maar deze werden soms als valspositief weggeschreven. In een latere fase (2012) werd een advies van de Anti-Money Laundering-Unit tot het beëindigen van de zakelijke relatie niet opgevolgd (Nationale Bank, 2018).

Hoewel de twee affaires vergelijkbaar zijn voor wat betreft de aard en omvang van de overtredingen, werd er totaal verschillend op gereageerd. De casus ING vulde dagenlang de voorpagina's van de landelijke dagbladen. Dat de grootste bank van de Lage Landen, die bovendien tien jaar eerder tot tweemaal toe door de overheid van een faillissement moest worden gered, nu zo'n hoge boete kreeg opgelegd, leidde tot grote maatschappelijke en politieke kritiek. De aandacht richtte zich in de eerste plaats op het gedrag en de cultuur van banken. Hoe kon het tien jaar na de financiële crisis opnieuw zo fout gaan? Had(den) de bank(en) dan niets van de crisis geleerd (De Correspondent, 6 september 2018)? De affaire werd als 'buitengewoon ernstig' bestempeld door de minister van Financiën en leidde tot een 
'nieuwe deuk in het maatschappelijk vertrouwen in de bankensector' (Het Financieele Dagblad, 6 september 2018). Het feit dat ING eerder in het jaar al onder vuur kwam te liggen vanwege de salarisrel rondom haar bestuursvoorzitter en de problemen in haar persbericht afdeed als 'regelgevingskwesties'1 deed de kritiek alleen maar aanwakkeren.

Maar er was niet alleen kritiek op de bank zelf en de ernst en omvang van de overtredingen. Ook de toezichthouders moesten het ontgelden. De kritiek richtte zich onder andere op De Nederlandsche Bank (DNB), die als toezichthouder verantwoordelijk is voor het reilen en zeilen binnen banken. De problemen bij ING waren al veel langer bekend, maar DNB zou daartegen onvoldoende hebben doorgepakt (NRC, 8 september 2018). Bovendien moest de toezichthouder bekendmaken dat meer banken onvoldoende maatregelen treffen om witwassen tegen te gaan (Het Financieele Dagblad, 25 september 2018). Maar ook het OM kreeg kritiek. Hoewel de transactie met ING in omvang de vijfde schikking ooit aan een bank opgelegd was en voor Nederlandse begrippen de hoogste ooit (NRC Handelsblad, 8 september 2018), werd het OM klassenjustitie verweten (vaste Kamercommissie Financiën, 17 oktober 2018) en werd de schikking in een hoofdredactioneel commentaar van dagblad Trouw als onbevredigend aangeduid (Trouw, 6 september 2018). ING is met een vermogen van 846 miljard euro de grootste bank van de Lage Landen en de tiende bank van Europa. ${ }^{2}$ Het nettoresultaat van de bank was gestegen van 4,3 miljard euro in 2016 tot 5,1 in 2017 (ING 2018, p. 25) en in het eerste halfjaar van 2018 maakt ING een winst van 2,6 miljard euro. Daarbij staat de boete van 775 miljoen euro in schril contrast. De discussie richtte zich dan ook vooral op de vraag of de transactie niet op gespannen voet stond met het rechtsgevoel, en of een dergelijke ernstige zaak niet in het openbaar door de strafrechter zou moeten worden beoordeeld (vaste Kamercommissie Financiën, 17 oktober 2018).

De affaire bij BNP Paribas Fortis daarentegen kwam pas maanden nadat de boete was opgelegd in de openbaarheid. Het was zelfs helemaal niet de bedoeling dat ooit bekend zou raken dat de bank de boete had gekregen, 'om de bank geen “onevenredig nadeel” te berokkenen' (Bové \& Broens, 2018). De boete werd daartoe ook geanonimiseerd gepubliceerd. ${ }^{3}$ Hoewel de toezichthouder een boete van 550.000 euro had voorgesteld, werd die uiteindelijk door de sanctiecommissie verlaagd tot 300.000 euro. Die verlaging werd in de sanctienota verantwoord op basis van de goede medewerking die de bank verleende, de beperkte voordelen die de bank had bij het behouden van de klantrelatie, de afwezigheid van bedrieglijk opzet en de continue verbetering van de werkprocessen die de bank heeft aangetoond (Nationale Bank, 2018). Toen uiteindelijk uitlekte dat het ging om BNP

1 Zie https://www.ing.nl/nieuws/nieuws_en_persberichten/2018/09/Ing-bereikt-schikking-metnederlandse-autoriteiten-over-regelgevingskwesties-bij-ing-nederland.html.

2 Zie https://www.businessinsider.nl/dit-zijn-de-50-grootste-banken-van-europa-nederland-ruktop-met-een-bank-in-de-top-10-waarvan-de-baas-onlangs-een-salarisverhoging-misliep/.

3 De bekendmaking van de beslissing is verplicht, maar dit kan geanonimiseerd gebeuren als de financiële stabiliteit verstoord dreigt te worden, een onevenredig nadeel dreigt, een beroepsprocedure is ingesteld of een lopende strafrechtelijke procedure in het gedrang komt (art. 36/11, par. 6 van de wet van 22 februari 1998). 
Paribas Fortis, kwam er slechts wat voorzichtige kritiek op de beperkte sanctie die de bank kreeg, zeker in vergelijking met buitenlandse banken die in dezelfde positie zaten (De Tijd, 2018). Ook hier betrof het een bank die met overheidsgeld van het faillissement werd gered (vroegere Fortis Bank). Het nettoresultaat voor 2017 was 7,8 miljard euro (BNP Paribas Fortis, 2018). Hoewel het de hoogste boete is die tot nu toe gegeven werd door de toezichthouder in deze context (wanneer we uitgaan van de gepubliceerde boetes ${ }^{4}$ ), staat ze hoe dan ook in schril contrast met de miljoenenboete voor ING, net aan de andere kant van de grens.

Deze ambivalente reacties op de affaires bij ING en BNP Paribas Fortis zijn illustratief voor hoe er meer in het algemeen wordt gereageerd op organisatiecriminaliteit. De casus ING staat daarbij symbool voor een klimaat waarin de aanpak van organisatiecriminaliteit steeds punitiever is geworden (Van Wingerde, 2012; Huisman, 2016; Huisman \& Kleemans, 2017; Beckers, 2017). Niet alleen is er steeds meer aandacht voor de maatschappelijke en financiële schade van organisatiecriminaliteit, die veel hoger is dan die van commune delicten (McGurrin \& Friedrichs, 2010), ook worden grote ondernemingen en hun bestuurders niet automatisch meer als respectabele leden van de samenleving gezien, maar als 'bad guys' die ernstige delicten plegen (Cullen e.a., 2009). Tot slot zijn de boetes voor organisatiecriminaliteit de afgelopen jaren ook steeds hoger geworden, zo laat Beckers (2017) in zijn studie naar de strafrechtelijke aanpak van organisatiecriminaliteit zien. De casus bij BNP Paribas Fortis laat tegelijkertijd zien dat in de reacties op organisatiecriminaliteit nog altijd een zekere ambiguïteit ten aanzien van de ernst van de gedragingen te herkennen is. Het feit dat de bank en de toezichthouder de casus het liefst buiten de openbaarheid hadden gehouden en waren overgegaan tot business as usual doet afbreuk aan de boodschap dat dergelijk gedrag laakbaar en strafbaar is - iets waarvoor Edwin Sutherland (1983) al waarschuwde.

Het bovenstaande roept de vraag op welke ontwikkelingen er de afgelopen jaren te zien zijn in de aard en omvang van organisatiecriminaliteit en de perceptie en aanpak ervan. Hebben de financiële crisis en de schandalen van de laatste jaren tot meer normbesef bij ondernemingen geleid, of draagt al die aandacht juist bij aan een zekere murwheid ten aanzien van organisatiecriminaliteit? Heeft de strengere aanpak de afgelopen jaren impact gehad? Hebben hoge boetes, zoals bij ING, effect? Wat kan er van compliancemaatregelen, zoals de in Nederland in 2015 ingevoerde bankierseed, worden verwacht? En wat betekenen veranderingen in de aard en omvang van (verschillende vormen van) organisatiecriminaliteit voor de perceptie en aanpak ervan?

4 Eerder werden sinds januari 2015 drie minnelijke schikkingen voorgesteld en aanvaard van 250.000, 50.000 en 250.000 euro en drie administratieve sancties van 300.000, 250.000 en 50.000 euro voor inbreuken op de wet van 11 januari 1993 tot voorkoming van het gebruik van het financiële stelsel voor het witwassen van geld (B.S. 28 januari 1993). Die werden elk geanonimiseerd gepubliceerd. 


\section{Een nieuw themanummer}

Deze vragen waren de aanleiding voor dit themanummer. In 2004 verscheen het eerste themanummer van Tijdschrift voor Criminologie gewijd aan 'Organisatiecriminaliteit'. Dat nummer vormde een eerste inventarisatie van het criminologisch onderzoek in het Nederlandse taalgebied naar dit thema. Niet lang daarna, in 2008, verscheen een tweede themanummer, getiteld 'Toezicht en compliance', ditmaal gericht op de verschillende vormen van sociale controle met betrekking tot organisatiecriminaliteit en op de manier waarop compliance (of regelnaleving) wordt nagestreefd. Nu, tien jaar later, is het tijd voor een nieuwe stand van zaken. Het onderzoek in dit domein heeft - met name in Nederland - een 'vaste plaats' in de criminologie verworven (Van Erp e.a., 2015). Dat roept de vraag op waar we nu staan in het onderzoek naar organisatiecriminaliteit en de aanpak ervan. In dit inleidende artikel gaan we in op enkele ontwikkelingen in het onderzoek naar organisatiecriminaliteit. Dat doen we aan de hand van drie vragen: (1) Wat zijn de belangrijkste ontwikkelingen in de wijze waarop onderzoek naar organisatiecriminaliteit wordt verricht? (2) Waar gaat het onderzoek over? Wat zijn de belangrijkste thema's? (3) Wat missen we en wat zijn de belangrijkste blinde vlekken in onderzoek naar organisatiecriminaliteit?

\section{Onderzoek doen naar organisatiecriminaliteit}

Hoewel Sutherland $(1949 ; 1983)$ de studie naar organisatiecriminaliteit begon met een kwantitatief overzicht van de aard en omvang van de delicten gepleegd door de 70 grootste bedrijven uit de Verenigde Staten, is het meeste onderzoek naar organisatiecriminaliteit kwalitatief van aard. Kwantitatief onderzoek in dit domein is dan ook niet eenvoudig op te zetten (Parker \& Lehmann Nielsen, 2009; Gibbs \& Simpson, 2009; Walburg, 2015). Het vereist in de eerste plaats dat gegevens over de aard en omvang van normoverschrijdingen door bedrijven en de daarbij opgelegde sancties beschikbaar en betrouwbaar zijn. Waar we zien dat toezichthouders in Angelsaksische landen vanaf hun oprichting begin jaren zeventig al uitgebreide databestanden bijhouden over de aard, omvang en resultaten van hun inspecties en de mate van regelnaleving door bedrijven (Cohen, 2000), staan de registratie en het beheer van dergelijke gegevens in Nederland en België nog in de kinderschoenen. Ook als er wel gegevens beschikbaar zijn, zijn deze meestal niet verzameld met het oog op wetenschappelijk onderzoek en kunnen ze registratiefouten bevatten. Daar komt nog bij dat bij de opsporing en handhaving van organisatiecriminaliteit vele verschillende toezichthouders betrokken zijn. Dit leidt ertoe dat gegevens over de aard en omvang van de geconstateerde overtredingen verspreid bij diverse instanties moeten worden opgevraagd en vanwege registratie- en interpretatieverschillen zeer moeilijk aan elkaar gekoppeld kunnen worden en met elkaar kunnen worden vergeleken. Dat belemmert de mogelijkheden om (vormen van) organisatiecriminaliteit door de gehele keten in kaart te brengen (Verhage, 2014). Tot slot bieden officiële criminaliteits- of nalevingsgegevens voornamelijk inzicht in de prioriteiten en capaciteit van handhavingsin- 
stanties (Van de Bunt \& Huisman, 2007; Walburg, 2015). Organisatiecriminaliteit is immers meestal niet het type criminaliteit dat zich als 'vanzelf' bij de instanties verantwoordelijk voor opsporing en handhaving aandient. Los van de methodologische vragen rondom de beschikbare data, richt veel onderzoek naar organisatiecriminaliteit zich bovendien op ondernemingsactiviteiten die in beginsel legaal, maar wel schadelijk zijn. Dat impliceert dat dergelijke gedragingen geen onderdeel uitmaken van officiële criminaliteits- of nalevingsgegevens.

Veel onderzoek naar organisatiecriminaliteit betreft dan ook casestudieonderzoek (Verhage, 2011), veelal gebaseerd op een analyse van open bronnen rondom grote affaires, zoals de dieselfraude bij Volkswagen (Van Rooij \& Fine, 2018; Spapens, 2018), de corruptieaffaire bij Siemens (Klinkhammer, 2015), de Madofffraude (Van de Bunt, 2010) of de affaire rond het gifschip de Probo Koala (Van Wingerde, 2015).

Niettemin zijn er de laatste jaren diverse meer kwantitatieve studies naar organisatiecriminaliteit verschenen en zien we daarin ook nieuwe ontwikkelingen. Kluin (2014) is een van de eersten die er in het Nederlandse taalgebied in is geslaagd om over een langere periode data te verzamelen over het nalevingsgedrag van bedrijven. In haar dissertatie onderzocht zij in hoeverre en op welke wijze de handhaving van het Besluit risico's zware ongevallen van invloed is op de naleving van vijftien bedrijven in de chemische industrie in het Rijnmondgebied. Haar onderzoek betreft onder andere een trendanalyse van alle overtredingen en de handhaving ervan over de vijftien bedrijven op het terrein van milieu en arbeidsomstandigheden in de periode 1999-2011. De belangrijkste meerwaarde van het onderzoek is dat Kluin niet alleen inzicht biedt in de 'criminele carrière' van deze bedrijven, maar ook in de kennislacunes die er zitten in het toezicht op deze bedrijven. Zoals hierboven toegelicht, is een dergelijk onderzoek geen sinecure. Kluins analyse betrof dan ook nog 'slechts' vijftien bedrijven en richtte zich alleen op de bestuursrechtelijke handhaving van overtredingen. In een onderzoek naar de strafrechtelijke aanpak van organisatiecriminaliteit analyseerde Beckers (2017) ongeveer 2.500 strafbladen van rechtspersonen en daarbij betrokken individuele personen. De steekproef betrof onder andere 1.000 strafbladen at random geselecteerd van in Nederland geregistreerde rechtspersonen en 237 strafbladen van de 250 grootste Nederlandse ondernemingen gemeten naar hun omzet. De analyse van 1.000 strafbladen laat zien dat de rechtspersonen verantwoordelijk zijn voor in totaal 2.453 delicten, waarvan een groot deel bestaat uit verkeersdelicten. Voor de 237 grote ondernemingen geldt dat ruim 80 procent geen strafblad had. De 50 bedrijven die wel een strafblad hadden, waren verantwoordelijk voor 534 delicten, meestal milieudelicten. Beckers laat bovendien zien dat het merendeel van de delicten buitengerechtelijk wordt afgedaan en dat de opgelegde sancties relatief laag zijn, gemiddeld respectievelijk 917 euro (voor alle rechtspersonen) en 5.059 euro (voor de 237 grootste bedrijven).

Deze analyses zijn van grote waarde voor het inzicht in de aard en omvang van de organisatiecriminaliteit en de handhaving daarvan en maken duidelijk dat opsporings- en handhavingsautoriteiten grote moeite hebben om deze vorm van criminaliteit effectief aan te pakken. 
De sterke nadruk op casestudieonderzoek brengt mee dat veel onderzoek naar organisatiecriminaliteit zich doorgaans richt op omstandigheden binnen bedrijven en markten die eraan bijdragen dat normoverschrijdingen plaatsvinden. Daardoor is weinig bekend over factoren in de persoonlijke ontwikkeling van daders die een bijdrage leveren aan organisatiecriminaliteit. In zijn studie onder 644 voor serieuze fraude veroordeelde daders vult Van Onna (2018) deze lacune op. Aan de hand van de levensloopbenadering analyseert Van Onna hoe de criminele ontwikkeling van deze fraudeurs eruitziet en welke factoren in de levensloop die ontwikkeling beïnvloeden. Van Onna laat zien dat de criminele carrière van fraudeurs - anders dan bij daders van commune delicten - voor een grote meerderheid van de daders in de volwassenheid begint. Daarbij spelen persoonlijke percepties over hoe zij zichzelf zien en hoe zij aankijken tegen veranderingen een belangrijke rol. Daarmee zijn de risicofactoren voor fraude in belangrijke mate te herleiden naar risicofactoren in het beroeps- en privéleven en niet naar risicofactoren uit de jeugd, zoals bij veel andere vormen van criminaliteit.

Hoewel de levensloopbenadering voornamelijk is toegepast op individuele daders, kan een levensloopbenadering van organisaties belangrijke nieuwe inzichten in de aard en omvang van organisatiecriminaliteit en de factoren die daaraan bijdragen opleveren, zo betogen Kluin, Blokland, Huisman, Peeters, Wiering en Jaspers in hun bijdrage aan dit themanummer. Op basis van longitudinale data tussen 2006 en 2017 analyseren zij de regelovertredingen door 494 chemische bedrijven in Nederland. Na een inventarisatie van de omvang en frequentie van de normoverschrijdingen zijn de auteurs nagegaan of zij daarin patronen konden ontdekken voor verschillende groepen bedrijven, en hebben zij onderzocht welke branche- en bedrijfskenmerken met die patronen samenhangen. Niet alleen bevat het onderzoek unieke data, tevens laat het onderzoek zien dat ook bedrijven een levensloop kennen die beïnvloedt of en in hoeverre bedrijven zich schuldig maken aan normoverschrijdingen. Dat is een belangrijk inzicht, dat de komende jaren diverse nieuwe vervolgstudies mogelijk maakt.

De tot dusver besproken onderzoeken waren niet mogelijk geweest zonder toegang tot de organisaties die de gegevens over regelovertredingen en de handhaving verzamelen. Hoewel de mogelijkheden daartoe - afgaande op de hierboven genoemde studies, die in een relatief kort tijdsbestek na elkaar zijn verschenen lijken te groeien, blijven casestudies en kwalitatieve analyses van belevingen en achtergronden van daders een belangrijke bron van kennis over organisatiecriminaliteit. Daders zelf zijn daarbij natuurlijk een belangrijke - maar ook moeilijk toegankelijke - bron van informatie. Niettemin zien we de laatste jaren steeds vaker documentaires of biografieën die de dader aan het woord laten en vanuit zijn perspectief reflecteren op de regelovertredingen en de strafrechtspleging. De documentaire Unraveled (2011) over de fraude van de New Yorkse topadvocaat Marc Dreier is hier een mooi voorbeeld van. Dreier werd in 2008 gearresteerd voor een grootschalige investeringsfraude. De fraude van Dreier zou de boeken ingaan als een van de grootste van de afgelopen decennia, ware het niet dat daags nadat Dreier werd gearresteerd een nog veel grotere fraude bekend werd, namelijk die van Bernard Madoff. De documentaire laat Dreier zien tijdens zijn huisarrest in afwachting van de uitspraak. Hij vertelt daarin over zijn motieven voor de 
fraude en zijn beleving van zijn nieuwe situatie en het vooruitzicht van zijn gevangenschap. Dreier werd in 2009 veroordeeld tot twintig jaar gevangenisstraf. Maar ook criminologische onderzoekers slagen er soms in om met daders zelf te spreken en hun ervaringen op te tekenen. Een mooi voorbeeld van deze kruisbestuiving is de bijdrage van Huisman en Lesmeister in dit nummer. Dennis Lesmeister is een van de hoofdrolspelers in de vastgoedfraudezaak die vooral bekend is geworden onder de naam 'Klimop'. Lesmeister werd in 2015 veroordeeld tot een gevangenisstraf van drie jaar voor valsheid in geschrifte, niet-ambtelijke omkoping en deelname aan een criminele organisatie. In de laatste fase van zijn strafexecutie zocht Lesmeister contact met Huisman, wat leidde tot het artikel in dit themanummer. Vanuit het perspectief van Lesmeister analyseren de auteurs de gevolgen en beleving van de strafrechtspleging, een onderwerp dat tot nu toe onderbelicht is gebleven in de criminologische literatuur.

Tot slot wordt kennis over organisatiecriminaliteit niet alleen gegenereerd door criminologische onderzoekers verbonden aan universiteiten, maar in toenemende mate ook door ngo's en onderzoeksjournalisten. In aanloop naar het World Economic Forum, dat eerder dit jaar in Davos plaatsvond, publiceerde Greenpeace het rapport Justice for people and planet, met de ondertitel Ending the age of capture, collusion and impunity (2018). Het rapport bespreekt twintig zaken waarin multinationals, gebruikmakend van wet- en regelgeving, belastingverdragen, internationale afspraken en gebreken in het functioneren van toezicht en handhaving, schade toebrengen aan mens, milieu en economie en critici de mond snoeren. Een ander voorbeeld is het International Consortium of Investigative Journalists (ICIJ), dat in april 2016 de zogeheten Panama Papers publiceerde. De Panama Papers gaan over 11,5 miljoen gelekte bestanden van het Panamese advocatenkantoor Mossack Fonseca, dat gespecialiseerd was in het opzetten en managen van fiscale constructies in offshore jurisdicties, zoals de Britse Maagdeneilanden. Deze bestanden lieten zien hoe de rijke mondiale elite (zowel individuen als bedrijven) verschillen in belastingregels tussen jurisdicties uitbuit om zo haar financiën en rijkdom te beheren. In 2017 kwamen daar de Paradise Papers bij, waarin journalisten in 67 landen de gegevens van negentien bedrijvenregisters en twee offshore advieskantoren publiceerden. Geheimen van diverse grondstoffenhandelaren, politici en voetbalclubs kwamen op straat te liggen, waardoor belangenconflicten, oneerlijke concurrentie en corruptie werden aangetoond.

Veel van de schandalen van de afgelopen jaren zijn via dergelijke onderzoeksplatforms aan het licht gekomen. Zo beschouwd, is de casus ING een klassieke casus die door opsporing door de FIOD en het OM kon worden aangepakt. In grote lijnen zien we bovendien dat de aandacht van organisatiecriminologen en onderzoeksjournalisten, wellicht mede daardoor, ook verschuift van voornamelijk aandacht voor de 'harde' vormen van fraude, corruptie en overtredingen van de (straf)wet naar een bredere aandacht voor en verontwaardiging over social harms en maatschappelijke ongelijkheid die het gevolg is van de activiteiten van ondernemingen. Hierbij denken we aan het creatief boekhouden, belastingontwijking/ tax engineering enzovoort. Een voorbeeld hiervan is het onderzoek van de Euro- 
pese Commissie van 2017 naar bedrijven als Ikea, Starbucks, Amazon en Apple, die belastingafspraken maakten met landen (waaronder Nederland) en zo grote bedragen aan belasting konden ontwijken (The Guardian, 18 december 2017). Vanuit de aandacht voor ook deze meer 'softe' (of grijze) vormen van organisatiecriminaliteit zien we dan ook een verbreding van het onderzoeksdomein.

\section{Waar doen organisatiecriminologen onderzoek naar?}

Kijken we naar de dissertaties die sinds het vorige themanummer in het Nederlandse taalgebied zijn verschenen, dan zien we een aantal thema's terugkomen: corruptie, milieucriminaliteit, handhaving van organisatiecriminaliteit en onderzoek met een focus op de daders van organisatiecriminaliteit. Een eerste thema dat in verschillende proefschriften werd bestudeerd, is corruptie en onethisch gedrag.

In een onderzoek naar de perceptie van Vlaamse burgers en politiemedewerkers op corruptie bevestigde Dormaels (2014) de bevindingen van Peters en Welch (1978), dat situationele kenmerken de perceptie op wat corrupt gedrag is beïnvloeden. Die situationele kenmerken verwijzen naar de vragen of er een overheidsfunctionaris is betrokken, of er persoonlijk voordeel is, hoe groot dat voordeel is, en welke andere partij bij de omkoping is betrokken. De situatie alleen is echter onvoldoende om variaties in percepties op corruptie te verklaren, omdat ook de rol van betekenisvolle anderen meespeelt (vgl. Sutherlands differentiëleassociatietheorie). Zo stelt Dormaels op basis van een bevolkingssurvey en focusgroepen vast dat financiële rechercheurs strenger, maar ook meer selectief zijn dan gewone politieagenten in hun perceptie op welk gedrag corrupt wordt genoemd. Respondenten met een hogere sociaaleconomische status hebben meer begrip voor 'grand corruption' en respondenten met een lagere sociaaleconomische status zijn toleranter voor 'petty corruption'.

Gorsira (2018) gaat eveneens in op het thema corruptie. Zij beantwoordt in haar proefschrift de vraag waarom ambtenaren en ondernemers zich inlaten met omkoping en wat dat betekent voor de aanpak ervan. Ze verschaft dus inzicht in zowel actieve als passieve omkoping en bestudeert verklarende kenmerken van de individuen, hun interacties en de organisaties waarvoor ze werken. Het onderzoek omvat twee surveystudies, een experiment en een dossieronderzoek. De resultaten tonen aan dat een afweging van kosten en baten corruptie kan verklaren, maar belangrijker iemands moreel kompas. Daarmee wijst Gorsira op het belang van het versterken van sociale en persoonlijke normen in de aanpak van corruptie. Daarnaast stelt ze dat het ethische klimaat binnen organisaties corrupte keuzes kan beïnvloeden, en sterker nog, dat een organisatiecultuur die als egoïstisch wordt ervaren, de kans op corruptie vergroot. Gorsira stelt daarom dat ondernemingen verantwoordelijk kunnen worden gesteld om corruptie tegen te gaan door middel van een beter ethisch klimaat, waarin leidinggevenden een voorbeeldrol opnemen, in combinatie met situationele oplossingen als functiescheiding en -roulatie. 
Twee andere afgeronde promotieonderzoeken houden het bredere thema van ethische beslissingen en onethisch gedrag tegen het licht. Het promotieonderzoek van Loyens (2015) analyseerde op basis van de grid-group-cultuurtheorie hoe organisatiekenmerken van invloed zijn op ethische dilemma's waarmee 'street level bureaucrats' (Lipsky, 1980) geconfronteerd worden. Deze vraag beantwoordde ze via etnografisch onderzoek bij diverse teams van de Belgische sociale inspectie en politie. Loyens toont aan dat eerstelijns officieren niet louter beleid implementeren, maar ook beleid ontwikkelen door afhankelijk van de specifieke situatie bepaalde richtlijnen toe te passen of de richtlijnen wat te 'buigen'. Loyens onderzocht eveneens redenen voor het al of niet rapporteren van wangedrag van collega's. Deze bleken complexer dan vaak in politieliteratuur over de 'blue code of silence' of in literatuur over klokkenluiders werd vastgesteld. Op basis daarvan beargumenteerde ze het belang van maatwerk met klokkenluidersregelingen, afgestemd op de complexe cultuur van organisaties (Loyens, 2013).

In een onderzoek naar onethisch werknemersgedrag onderzocht Wouters (2016) de invloed van diverse typen organisatiecultuur op onethisch werknemersgedrag, eveneens op basis van de grid-group-cultuurtheorie. Door middel van online surveys bij 23 organisaties van de Belgische federale overheid liet Wouters zien dat onbalans in organisatiecultuur bepaalde vormen van onethisch werknemersgedrag kan beïnvloeden. Corruptie en het aanvaarden van voordelen waren twee vormen van onethisch werknemersgedrag die tegen het licht werden gehouden. De bevindingen waren hiervoor niet eenduidig, maar gaven wel aan dat er meer corruptie geobserveerd wordt wanneer respondenten een meer individualistische cultuur en een bepaalde mate van apathie in hun organisatie opmerken.

In de kroniek van dit themanummer geven Nelen en Kolthoff een stand van zaken van ambtelijke en bestuurlijke corruptie in Nederland. Ze beantwoorden daarbij, in de eerste plaats, de vraag wat we weten over de aard en de ernst van ambtelijke en bestuurlijke corruptie en of daarin trends zijn op te merken. Ten tweede bespreken ze de relevante ontwikkelingen die zich in de bestrijding en preventie van corruptie hebben voorgedaan.

Een tweede thema dat in promotieonderzoek aan bod kwam, is milieucriminaliteit. Naast het al eerder aangehaalde onderzoek van Kluin (2014), dat zich in Nederland afspeelde, doen criminologen ook veelvuldig onderzoek naar de gevolgen van productieprocessen van ondernemingen voor mens, milieu en economie in andere landen.

In een casestudie over de grensoverschrijdende handel in e-waste en tropisch hardhout tussen België en West-Afrika ging Bisschop (2012) na welke kenmerken van de sociale organisatie deze fenomenen kunnen verklaren en welk controle- en preventiemaatregelen het best op deze complexe sociale organisatie waren afgestemd. Winst bleek een zeer belangrijke verklarende factor, maar de sociale organisatie werd door een combinatie van individuele, organisatorische en maatschappelijke factoren vormgegeven. Voortbouwend op deze inzichten, ging deze studie in op het beheer van deze twee handelsstromen. De bevindingen tonen aan dat de theoretische modellen van responsieve regulering en netwerkgovernance (Braithwaite, 2008; Holley e.a., 2012) theoretisch of normatief een goede basis bieden voor controle en preventie van transnationale milieucriminaliteit. In de 
praktijk schieten ze echter tekort omdat milieu, economie, duurzame ontwikkeling en criminaliteitsbestrijding op gespannen voet met elkaar staan in de aanpak van milieucriminaliteit (Bisschop, 2015).

Mol (2017) focuste in haar proefschrift op de milieuschade ten gevolge van de productie van palmolie in Colombia. Ze bestudeerde dit vanuit een groen criminologisch perspectief en legde de constructies en praktijken van palmolieproducenten bloot. Daarnaast kreeg ze op basis van etnografisch onderzoek een beeld van de werkelijke en gepercipieerde realiteit van de schade in deze context. Zo toont zij aan dat de praktijken van de palmolie-industrie aan conventionele definities van criminaliteit beantwoorden, maar dat er tegelijk veel ernstige sociale en milieuschade mee gepaard gaat die niet onder strikt legalistische definities van criminaliteit valt.

Een derde onderwerp is de handhaving en dan meer bepaald de strafrechtelijke (Beckers, 2017) of bestuursrechtelijke (Mein, 2015) afhandeling van organisatiecriminaliteit, de effecten van verschillende vormen van publieke en private handhaving (Van Wingerde, 2012), compliance (Verhage, 2011) en de private opsporing (Meerts, 2018).

In haar onderzoek naar de handhaving van de antiwitwaswetgeving door banken en compliance officers werd door Verhage op basis van een survey voor compliance officers en het interviewen van actoren die actief zijn in de antiwitwasaanpak, het beeld geschetst van een antiwitwascomplex. In dat complex werken verschillende publieke actoren aan de strijd tegen witwassen. Dat complex wordt echter in sterke mate ondersteund door een groeiende compliance-industrie: een commerciële markt van vraag en aanbod. Deze twee systemen hebben een wederzijds versterkend effect: hoe meer nadruk op het belang van de aanpak van witwassen, hoe meer vraag naar ondersteuning en advies, en omgekeerd.

Compliance officers bevinden zich binnen de banken in een zeer moeilijke positie (zij moeten immers vaak 'anticommerciële' beslissingen nemen) en krijgen hier vanuit de publieke actoren bovendien weinig input voor, waardoor ze zelf op zoek moeten gaan naar de optimale manier om witwassen te detecteren. Door de beperkte samenwerking en informatie-uitwisseling tussen publieke (FIU, politie, toezichthouders) en private (compliance officers/banken) actoren wordt er dan ook in de aanpak van witwassen vaak naar dezelfde usual suspects gezocht, waardoor er sprake is van een selffulfilling prophecy: we vinden vooral dat wat we zoeken.

De hoge boetes die onder andere aan ING zijn opgelegd, roepen de vraag op of ze ook effectief zijn. Van Wingerde (2012) deed onderzoek naar de afschrikwekkende werking van sancties onder 40 bedrijven in de Nederlandse afvalbranche. Haar onderzoek laat zien dat er van sancties niet een direct afschrikwekkende werking uitgaat, maar eerder een indirect effect: voor zover sancties afschrikken, komt die afschrikwekkende werking tot stand via de omgeving: negatieve publiciteit is veel afschrikwekkender dan een boete van de overheid. Dat effect hangt ten tweede af van het type bedrijf dat je voor je hebt. Sancties werken vooral bij bedrijven die toch al bereid waren tot regelnaleving. Effectieve sancties zouden dan ook juist aan moeten sluiten bij al bestaande normenstelsels die het gedrag van bedrijven beïnvloeden. Sancties moeten daarvoor niet alleen een dreigende, 
maar juist een morele boodschap communiceren en beargumenteren wat het afkeurenswaardige is aan het bestrafte gedrag.

Waar Beckers (2017) de strafrechtelijke afhandeling tegen het licht hield, bestudeerde Mein (2015) het gebruik van de administratieve boete in het financieel toezicht door de Autoriteit Financiële Markten (AFM) en DNB. Hij stelde vast dat de bestuurlijke boete wordt opgelegd voor zware overtredingen, terwijl zij in oorsprong werd ingevoerd om efficiënter tegen lichtere, frequent voorkomende overtredingen op te treden, waar anders geen gevolg aan werd gegeven. Mein stelt dat de boete zo op gelijke voet met het strafrecht komt te staan, maar zonder dezelfde rechtswaarborgen.

Zoals eerder opgemerkt, is het perspectief van de individuele dader onderbelicht gebleven in veel onderzoek naar organisatiecriminaliteit. Naast het al eerder genoemde onderzoek van Van Onna, richtte ook de studie van Kabki zich op de drijfveren van fraudeurs (Kabki, 2014). In zijn promotieonderzoek bestudeerde Kabki de werkwijzen en drijfveren van fraudeurs op basis van de analyse van 41 strafrechtelijke onderzoeken en gerechtelijke uitspraken over bankfraude, beleggingsfraude of faillissementsfraude en interviews met rechercheurs, veiligheidsverantwoordelijken bij banken en rechters. Hij maakt een onderscheid tussen vijf type fraudeurs, die elk specifieke implicaties met zich brengen voor de aanpak: de zonnekoning, de gelegenheidspakker, de gelegenheidszoeker, de crisisgedrevene en de stereotiepe crimineel.

\section{Blinde vlekken in onderzoek naar organisatiecriminaliteit en de aanpak ervan}

Bovenstaande summiere stand van zaken over onderzoek naar organisatiecriminaliteit in Nederland en België staat ons toe om enkele blinde vlekken of toch minstens ondergesneeuwde thema's in onderzoek te identificeren.

Onderzoek naar witteboorden- en organisatiecriminaliteit besteedt weinig aandacht aan de rol van diversiteit. Hoewel in de managementliteratuur al langer over de mogelijke invloed van het glazen plafond op onethisch gedrag in en door organisaties wordt nagedacht, hinkt criminologisch onderzoek erachteraan. Kluin en De Ruiter zetten genderdiversiteit en organisatiecriminaliteit in dit themanummer op de criminologische kaart. In hun systematische literatuurreview onderzochten ze in hoeverre bestaande theorieën over gender en organisatiecriminaliteit, zoals de situationele hypothese en de 'gendered theory of focal concerns', steun vinden in empirisch onderzoek. De resultaten lijken de hypothese te bevestigen dat met een toename van vrouwen op posities in de top van het bedrijfsleven een daling in de prevalentie van witteboordencriminaliteit te verwachten is. De auteurs geven echter aan dat genderdiversiteit en de genderkloof inzake toegang tot informele netwerken andere mogelijke verklaringen zijn.

Longitudinale studies waren tot voor kort eveneens een nagenoeg blinde vlek in de Nederlandse en Belgische organisatiecriminologie en zijn ook internationaal vrij beperkt. De levensloopcriminologie met een focus op individuele daders van organisatiecriminaliteit kwam reeds in de bovenvermelde promotieonderzoeken van Beckers (2017) en Van Onna (2018) aan bod. Kluin (2014) maakte er met 
haar eerder toegelichte promotieonderzoek een start mee dit ook op ondernemingen als overtreders te richten. Deze longitudinale focus op ondernemingen als daders van organisatiecriminaliteit zet ze samen met haar coauteurs in dit themanummer door.

Veel onderzoek naar organisatiecriminaliteit richt zich op de activiteiten van commerciële ondernemingen of op de rol van overheden als initiërende of faciliterende organisaties. Dat roept de vraag op welk ander type organisaties tot nu toe onderbelicht is gebleven in de studie naar organisatiecriminaliteit. Hoewel de Paradise Papers bijvoorbeeld aan het licht brachten dat meer dan 100 Amerikaanse universiteiten en hogescholen fiscale constructies via jurisdicties als Panama, de Bahama's en de Britse Maagdeneilanden gebruikten om zo min mogelijk belasting te hoeven betalen, zijn onderwijsinstellingen grotendeels over het hoofd gezien in discussies over organisatiecriminaliteit..$^{5}$ Ook hebben we de afgelopen jaren diverse voorbeelden gezien van ngo's die onder vuur kwamen te liggen door gedragingen van hun medewerkers. Zo kreeg Greenpeace International in 2014 grote maatschappelijke kritiek toen uitlekte dat haar directeur voor zijn woon-werkverkeer tussen Luxemburg en Amsterdam gebruikmaakte van het vliegtuig. ${ }^{6}$ Tot op zekere hoogte kan worden betoogd dat dergelijke organisaties veel kenmerken delen met de grote, complexe, multinationale ondernemingen waar ze vaak kritiek op hebben.

Hoewel we in dit themanummer ook uitdrukkelijk aandacht wilden besteden aan de rol van het toezicht op en de handhaving van organisatiecriminaliteit, ontvingen we daarover nauwelijks bijdragen. De vraag is hoe dat komt. Wordt daar weinig onderzoek naar gedaan, of richt dergelijk onderzoek zich niet of nauwelijks op organisatiecriminaliteit? In een recente bijdrage aan het tijdschrift Regulation \& Governance spreken Almond en Van Erp (2018) van een 'disciplinary gap' tussen het onderzoek naar toezicht en handhaving enerzijds en het onderzoek naar organisatiecriminaliteit anderzijds. Beide disciplines zijn langzamerhand steeds meer uit elkaar gegroeid. Een belangrijke reden daarvoor is dat veel onderzoek naar regulering, toezicht en handhaving zich richt op institutionele vragen rond de inrichting en het functioneren van het toezicht en veel minder op de normoverschrijdingen die ten grondslag liggen aan toezicht en handhaving. Andersom beperken organisatiecriminologen zich veelal tot het bestuderen van (de effecten van) bestuurlijke en strafrechtelijke handhaving en hebben vaak geen oog voor private vormen van handhaving. Bovendien, zo stellen Almond en Van Erp, maakt de beperkte generaliseerbaarheid van de vele casestudies in organisatiecriminologisch onderzoek dat de integratie van kennis in andere disciplines beperkt is gebleven. Almond en Van Erp besluiten hun analyse met een beschrijving van de wijze waarop de organisatiecriminologie van waarde kan zijn voor het onderzoek naar toezicht en regulering. Een van de belangrijkste bijdragen van de organisatiecriminologie ligt volgens hen in het vermogen om structurele machtsonge-

5 Zie https://www.theguardian.com/news/2017/nov/08/us-universities-offshore-fundsendowments-fossil-fuels-paradise-papers.

6 Zie https://www.theguardian.com/environment/2014/jun/23/greenpeace-defends-top-executiveflying-to-work. 
lijkheid tussen bedrijven en overheden enerzijds en maatschappijen anderzijds te signaleren en te problematiseren. Een dergelijk meer gepolitiseerd perspectief op organisatiecriminaliteit levert niet alleen belangrijke inzichten op over de aard en omvang van organisatiecriminaliteit, maar ook over de effecten en neveneffecten van verschillende vormen van publieke en private handhaving.

Samengevat, kennis verzamelen over en inzicht krijgen in de verklarende factoren en processen die aan organisatie- en witteboordencriminaliteit ten grondslag liggen, blijft ook vandaag een belangrijke doelstelling van de organisatiecriminologie. Op basis van dit themanummer stippen we enkele vragen aan die in het bijzonder aandacht verdienen. In de eerste plaats de vraag naar diversiteit en in hoeverre en op welke wijze diversiteit een een verklarende of beschermende rol voor witteboorden- en/of organisatiecriminaliteit speelt. Daarmee verwijzen we niet alleen naar gender, maar ook naar culturele achtergronden en de diversiteit binnen ondernemingen an sich. Een tweede vraag is gerelateerd aan het levenslooponderzoek van ondernemingen. In hun bijdrage aan dit themanummer hebben Kluin e.a. laten zien dat ook ondernemingen een levensloop hebben en dat de aard en omvang van de regelovertredingen verschilt al naar gelang de fase in die levensloop. Een interessante vervolgvraag is welke factoren binnen de levensloop van ondernemingen invloed hebben op hun (on)ethisch gedrag en hoe verschillende branche- en bedrijfskenmerken daarmee samenhangen.

Ten derde de hierboven reeds opgeworpen vraag welk ander type organisaties een rol spelen bij (de preventie en bestrijding van) organisatiecriminaliteit? Welke rol spelen ngo's, kennisinstituten en onderzoeksjournalisten? Naast een belangrijke rol in het ontdekken en zichtbaar maken van organisatiecriminaliteit, kunnen deze organisaties ook betrokken raken bij vormen van organisatiecriminaliteit. Hoe moeten we dat duiden en hoe is die verwijtbaarheid te verklaren?

Antwoord op deze vragen is tot slot essentieel om ook te begrijpen hoe (verschillende vormen van) toezicht en handhaving functioneren en om voorstellen te doen ter verbetering.

Bovenstaande vragen vormen voor veel criminologen die zich bezighouden met organisatiecriminaliteit - onder wie wijzelf - een belangrijke inspiratiebron, en we hopen dan ook dat dit themanummer aanzet tot nieuw organisatiecriminologisch onderzoek.

\section{Literatuur}

Almond, P. \& Erp, J. van (2018). Regulation and governance versus criminology. Disciplinary divides, intersections, and opportunities. Regulation \& Governance. doi:10.1111/ rego.12202.

Beckers, J.J.H. (2017). Tussen ideaal en werkelijkheid. Een empirische studie naar de strafrechtelijke aanpak van organisatiecriminaliteit in Nederland (diss. Rotterdam).

Bisschop, L. (2012). Governance of the illegal trade in e-waste and tropical timber. Case studies on transnational environmental crime (diss. Gent). Geraadpleegd op https://biblio. ugent.be/publication/3119336. 
Bisschop, L. (2015). Governance of the illegal trade in e-waste and tropical timber: case studies on transnational environmental crime. London: Routledge.

BNP Paribas Fortis (2018, 6 februari). Resultaten per 31 december 2018. Persbericht. Geraadpleegd op https://ondernemingen.bnpparibasfortis.be/nl/nieuws?n=bnpparibas-jaarlijkse-resultaten-2017.

Bové, L. \& Broens, B. (2018). BNP Paribas Fortis jarenlang te laks tegen witwassen. De Tijd, 22 september 2018. Geraadpleegd op https://www.tijd.be/ondernemen/banken/bnpparibas-fortis-jarenlang-te-laks-tegen-witwassen/10052091.html.

Braithwaite, J. (2008). Regulatory Capitalism: How it Works, Ideas for Making it Work Better. Cheltenham: Edward Elgar.

Bunt, H.G. van de (2010). Walls of secrecy and silence. The Madoff case and cartels in the construction industry. Criminology \& Public Policy, 9(3), 435-453. Bunt, H.G. van de \& Huisman, W. (2007). Organizational crime in the Netherlands. In: M. Tonry \& C. Bijleveld (eds.). Crime and justice in the Netherlands. Series Crime and Justice: a review of research, Vol. 35. Chicago: University of Chicago Press, 217-260.

Cohen, M.A. (2000). Empirical research on the deterrent effect of environmental monitoring and enforcement. Environmental Law Reporter, 30(4), 10245-10252.

Cullen, F.T., Hartman, J.L. \& Jonson, C.L. (2009). Bad guys: why the public supports punishing white-collar offenders. Crime, Law \& Social Change, 51(1), 31-44.

Dormaels, A. (2014). Perceptions of corruption in Flanders: surveying citizens and police. A study of the influence of occupational differential association on perceptions of corruption (diss. Gent). Geraadpleegd op https://biblio.ugent.be/publication/4435845.

Erp, J. van, Huisman, W. \& Vande Walle, G. (2015). Routledge handbook on white-collar and corporate crime in Europe. Abingdon: Routledge.

Gibbs, C. \& Simpson, S.S. (2009). Measuring corporate environmental crime rates: progress and problems. Crime, Law \& Social Change, 51(1), 87-107.

Gorsira, M. (2018). Corruption. Why two tango out of step (diss. Amsterdam VU). Geraadpleegd op http://dare.ubvu.vu.nl/handle/1871/55686.

Holley, C., Gunningham, N. \& Shearing, C. (2012). The new environmental governance. London: Earthscan. DOI: 10.4324/9781315067278.

Huisman, W. (2016). Een 'punitive turn' bij de aanpak van financieel economische criminaliteit? Tijdschrift voor Bijzonder Strafrecht en Rechtshandhaving, 4, 191-193.

Huisman, W. \& Kleemans, E. (2017). Organisatiecriminaliteit, georganiseerde criminaliteit en ondermijning. In: R. Staring, R. van Swaaningen \& K. van Wingerde (red.). Over de muren van stilzwijgen. Liber amicorum Henk van de Bunt. Den Haag: Boom criminologie, 535-548.

ING Bank (2018). ING Bank Annual Report 2017. Geraadpleegd op https://www.ing.com/ Investor-relations/Financial-Reports/Annual-reports.htm

Kabki, A. (2014). Fraude ontrafeld. Een studie naar de werkwijzen en drijfveren van fraudeurs. Den Haag: Boom Lemma.

Klinkhammer, J. (2015). Varieties of corruption in the shadow of Siemens: a modus operandi study of corporate crime on the supply side of corrupt transactions. In: J. van Erp, W. Huisman \& G. Vande Walle (eds.). The Routledge handbook of white-collar and corporate crime in Europe. London: Routledge, 318-335.

Kluin, M. (2014). Optic compliance. Enforcement and compliance in the Dutch chemical industry. Delft: TU Delft.

Lipsky, M. (1980). Street-level bureaucracy: dilemmas of the individual in public services. New York: Russell Sage Foundation. 
Loyens, K. (2013). Towards a custom-made whistleblowing policy. Using grid-group cultural theory to match policy measures to different styles of peer reporting. Journal of Business Ethics, 114(2), 239-249.

Loyens, K. (2015). Integrity secured. Ethical decision-making among street-level bureaucrats in the Belgian labour inspection and federal police (diss. Leuven). Geraadpleegd op https:// limo.libis.be/primo-explore/fulldisplay?docid=LIRIAS1908389\&context=L\&vid= Lirias\&search_scope=Lirias\&tab=default_tab\&lang=en_US\&fromSitemap $=1$.

McGurrin, D. \& Friedrichs, D.O. (2010). Victims of economic crime - on a grand scale. International Journal of Victimology, 8(2), 147-157.

Meerts, C.A. (2018). The semi-autonomous world of corporate investigators. Modus vivendi, legality and control. (diss. Erasmus Universiteit Rotterdam). Geraadpleegd op https://repub.eur.nl/pub/103864/

Mein, A.G. (2015). De boete uit balans. Het gebruik van de bestuurlijke boete in de praktijk van het financieel toezicht. Den Haag: Boom Lemma uitgevers.

Mol, H. (2017). A Green Criminological Perspective on the Politics of Palm Oil Harm. London: Palgrave Macmillan

Nationale Bank (2018). Beslissing van de sanctiecommissie van de Nationale Bank van België van 28 mei 2019 in de zaakX. Geraadpleegd op https://www.nbb.be/doc/cp/nl/2018/ 20180528_anonieme\%20versie_beslissing.pdf.

OM (Openbaar Ministerie). (2018). Onderzoek Houston. Het strafrechtelijk onderzoek naar ING Bank N.V. Feitenrelaas en beoordeling Openbaar Ministerie. Geraadpleegd op https://www.om.nl/actueel/nieuwsberichten/@103953/ing-betaalt-775/.

Onna, J. van (2018). Blurred lines. A study of white-collar crime involvement (diss. Amsterdam VU).

Parker, C. \& Lehmann Nielsen, V. (2009). The challenge of empirical research on business compliance in regulatory capitalism. Annual Review of Law and Social Science, 5, 45-70.

Peters, J.G. \& Welch, S. (1978). Politics, corruption, and political culture: a view from the state legislature. American Politics Quarterly, 6(3), 345-356.

Rooij, B. van \& Fine, A. (2018). Toxic corporate culture: assessing organizational processes of deviancy. Administrative Sciences, 8, 23. doi:10.3390/admsci8030023.

Spapens, T. (2018). The 'Dieselgate' scandal: a criminological perspective. In: T. Spapens, R. White, D. van Uhm \& W. Huisman (eds.). Green crimes and dirty money. London/New York: Routledge, 91-112.

Sutherland, E.H. (1983). White-collar Crime: the Uncut Version. New Haven, Conn.: Yale University Press.

Verhage, A. (2011). The anti money laundering complex and the compliance industry. Oxon: Routledge.

Verhage, A. (2014). Op zoek naar financieel-economische criminaliteit. In: Criminografische ontwikkelingen III: van (victim)survey tot penitentiaire statistiek (Vol. 9). Antwerpen: Maklu, 89-112.

Walburg, C. (2015). The measurement of corporate crime, an exercise in futility? In: J. van Erp, W. Huisman \& G. Vande Walle (eds.). The Routledge handbook of white-collar and corporate crime in Europe. London: Routledge, 25-38.

Wingerde, C.G. van (2012). De afschrikking voorbij. Een empirische studie naar afschrikking, generale preventie en regelnaleving in de Nederlandse afvalbranche (diss. Rotterdam). Nijmegen: Wolf Legal Publishers.

Wingerde, C.G. van (2015). The limits of environmental regulation in a globalized economy: lessons from the Probo Koala case. In: J. van Erp, W. Huisman \& G. Vande Walle (eds.). The Routledge handbook of white-collar and corporate crime in Europe. London: Routledge, 260-275. 
Wouters, K. (2016). Cultuur aan/op het werk. Een onderzoek naar de impact van cultuur op onethisch werknemersgedrag (diss. Leuven). Geraadpleegd op https://limo.libis.be/ primo-explore/fulldisplay?docid=LIRIAS1909624\&context=L\&vid=Lirias\&search_ scope=Lirias\&tab=default_tab\&lang=en_US\&fromSitemap $=1$. 